\title{
APPLICATION OF TAXATION E-SYSTEM TO THE UNDERSTANDING OF ACCOUNTING STUDENT AT BINA BANGSA UNIVERSITY
}

\author{
Ina Khodijah, Raden Irna Afriani \\ Universitas Bina Bangsa, Kota Serang, Indonesia \\ innakhodijah@gmail.com
}

\begin{abstract}
Online tax system is a change in the modern taxation system by using information technology that makes it easy for people to get services and information. But the knowledge of most taxpayers, especially students about the tax e-system is still low, so the Directorate General of Taxes needs to socialize the existence of this tax e-system. This study has the aim of how the use of taxation e-system in the form of e-registration system, e-spt system, e-filing system, and e-billing system has an influence on the understanding of accounting students. This research uses a descriptive quantitative method or approach. This research was conducted by distributing questionnaires to students who took the 2015 tax accounting accounting concentration at Bina Bangsa University, Banten. The results of this study concluded that partially the e-registration system and e-filling system affect the understanding of accounting students. While the e-spt system and e-billing system did not affect the understanding of accounting students. But simultaneously all e-registration system variables, e-system systems, e-filling systems and e-billing systems take affect to understanding of accounting students.
\end{abstract}

Keywords: Understanding of Accounting Student; Online Tax System; E-Registration System; E-SPT System; E-Filling System; E-Billing System

\section{INTRODUCTION}

The current taxation system in Indonesia shows rapid progress. This is evidenced of progress development taxation E-system which is a change in the modern taxation system by using information technology that makes it easy for the public to obtain services and information related to taxation. In addition, taxation agencies use this technology to facilitate tax reporting. It is undeniable that the existence of this taxation E-system can make easier for taxpayers to report taxes and issue modernization of modern tax administration using information technology that also follows technological advancements with esystem technology-based services such as e-spt, e-registration, e billing, e-filing, which is expected to improve more effective control and reporting mechanisms. With the renewal of this taxation e-system, it is hoped that it will be easier for taxpayers, register, renew, or delete any tax-related information that can be done from anywhere and any time. E-SPT aims to facilitate the public to submit SPT with an 
electronic SPT program that has been provided by the Directorate General of Taxes, e-filing and e-billing that is useful for reporting and paying taxes based on line and in real time. This online and real time-based service aims to save time, is very easy, precise and economical so as to produce services effectively and efficiently.

Before the tax reform, all tax activities were carried out manually, such as filling, reporting and payment made directly to the tax office. The ease in the modern tax administration system can also be applied in terms of tax administration services. A concrete example of the ease of the tax administration system is:

1. Taxpayers can register themselves online using e-Registration wherever they are without having to go through the tax office directly.

2. Taxpayers can also fill out the tax return by utilizing computer media in an e-SPT, with the eSPT sending data of the notification letter (SPT) can be done anywhere and anytime both inside and outside the country, does not depend on office hours and can also be done on holidays and without the presence of a Tax Officer.

3. Reporting tax returns online through e-Filing, can reduce the administrative burden of using tax paper reports.

4. Electronic payments through ebilling which can also make payments through the nearest ATM, Bank or post office.
This research was conducted at the University of Bina Bangsa Banten. One of the most prominent private campuses in the Serang region. Located in the area of the City of Serang. At first the University of Bina Bangsa was only a high school called the College of Economics (STIE) Bina Bangsa. University as a source producer human power in meeting intellectual needs. Especially Bina Bangsa University which has opened many study programs that can embrace the community to become a quality generation, which is produced from this university.

The accounting study program in particular has provided tax lessons. Basic taxation is obtained in the second semester while tax accounting is obtained in the fourth semester. Students should have studied tax for two semesters, they have understood taxation specifically regarding tax modernization in thiscase about tax technology even though it is not detailed in the university curriculum. However, not all students can quickly understand the development of taxation technology starting from the understanding, characteristics, recording, calculation, and reporting.

Heri Tavip Riyanto (2014) states that there are still many students who do not understand taxation. Students only understand the abbreviations and abbreviations. However, according to research Rahmatunnisa et al (2016) stated that the results of the study were foundthat the results of the research have a relationship between students' understanding of tax technology. 
This is due to the lack of knowledge of taxpayers especially students about the e-taxation system which is still low so that the

\section{LITERATURE REVIEW}

\subsection{Definition of tax.}

According to Mardiasmo (2018): "Tax is defined as people's contributions to the state treasury that can be imposed under the law without reciprocal or counterperformance services and are used to finance the State household."Understanding comes from the word basic understanding which means to understand. According to the Big Indonesian Dictionary, understanding means the process of how to understand or understand.

\subsection{Definition Of Comprehension}

Suharsismi (2009) understanding (comprehension) is how someone defends, differentiates, suspects, explains, expands, concludes, generalizes, gives examples, rewrites and estimates.

\subsubsection{E-registration system.}

Is a system that is connected by data communication devices based on softwareand hardware, used to manage the registration process, changes in taxpayer data, and inauguration or revocation of taxable entrepreneurs. The e-registration system is one of the electronic service products at the Directorate General of Taxes which is used to register new taxpayers who want to obtain a taxpayer identification number (NPWP). The e-Registration
Directorate General of Taxes needs to conduct socialization related to this e-taxation system in more depth.

system has become effectivesince 2005, namely since the issuance of Decree of the Director General of Tax Number: KEP-173 / PJ / 2004 dated 7 December 2004 concerning Procedures for Registration and Write-Off of Taxpayer Identification Number s well as the Inauguration and Revocation of Taxable Entrepreneurs with the e-Registration System that has been updated with the Regulations Director General of Taxes Number: PER-24 / PJ / 2009 dated March 16, 2009 concerning Procedures for Registration of Taxpayer Identification Numbers and or Inauguration of Taxable Entrepreneurs and Changes in Taxpayer Data and or Taxable Entrepreneurs with the e-Registration System. Changes in regulations from PER-24 / PJ / 2009 to PER-38 / PJ / 2013 brought significant changes regarding the procedures for registration with the e-Registration System, one of the most basic is that tax officers at the Tax Service Office (KPP) do not need again waiting for the registration file from the Taxpayer to carry out the NPWP validation process, besides that there are also many administrative changes.

\subsubsection{E-SPT system}

Understanding E-SPT system to Article 1 of the Regulation of the Directorate General of Tax Number PER-1 / PJ / 2014 is the taxpayer's tax return data in electronic form 
made by the taxpayer using the eSPT application provided by the Directorate General of Taxes.While the definition of e-SPT according to the DJP is a Notification Letter along with its attachments in digital form and reported electronically or by using computer media that is used to assist taxpayers in reporting tax payable and payment in accordance with the provisions of the applicable laws and regulations.

\subsubsection{E-filling system}

e-filings is a way to submit SPT or Annual Tax Return renewal which is done online and in real time through the DJP Online tax e-filing website or applications provided by

\section{RESEARCH METHOD}

\subsection{Data Collection Techniques}

Method is a procedure or way to find out something that has systematic steps (Usman and Akbar). The research approach that will be used in this research is Descriptive Research quantitative method with Survey technique where this method aims to directly examine whether there is a relationship between the understanding of accounting students toTax technology. This type of quantitative research is research data in the form of numbers and analysis using statistics (Sugiyono).

\subsection{Definitions of Variables Operation}

The dependent variable (dependent variable) in research used by researchers is the understanding of accounting students as $\mathrm{Y}$
ASP (Application Service Providers).

\subsubsection{E-billing system}

E-billing is an electronic-based tax payment method that is used to facilitate taxpayers to pay their taxes. This e-billing uses the billing code itself, which is the identification code issued through the billing system for a type of payment or tax payment to be made by the taxpayer. Billing system is a system that issues billing codes for payments or deposits of state revenue electronically, without the need to make a manual deposit (SSP, SSBP, SSPB).

variables. The independent variables used by researchers are:

$\mathrm{X} 1$ : The e-registration system variable,

$\mathrm{X} 2$ : e-SPT system variable

$\mathrm{X} 3$ : e-filling system variable

$\mathrm{X} 4$ : e-billing system variable.

Indicator of understanding of accounting students is an understanding of the taxation system, knowledge and understanding related to tax regulations and understanding of the taxation function.

Indicators of e-registration are awareness of registering NPWP, knowledge of applicable tax regulations and effectiveness of the taxation system.

The e-spt indicator is that the SPT submission can be done quickly through the internet network, the calculation is done quickly and precisely, the data submitted by the Taxpayer is always complete, the use 
of paper is more efficient and no SPT recording process is needed.

The e-filling indicator is the taxpayer's knowledge about e-filling, the efficiency of using e-filling, the quality of the system and the security of the system, and the quality of the information.

The e-billing indicator is the ease of tax payment, the speed in tax payment and the accuracy in calculating and filling in the tax payment letter Taxpayer.

\subsection{Population and Sample}

The population in this study was Accounting Students who took tax accounting concentrations at the Bina Bangsa University Class of 2015 totaling 98 students.

Based on this population, the determination of a representative sample in this study is to use accidental sampling technique, is a sampling technique based on accidental / accidental meeting with

\section{RESULT AND DISCUSSION}

\subsection{Results}

The results of the calculation of the validity of the questionnaire on accounting student understanding variables (Y), e-registration system variables (X1), e-SPT system variables (X2), e-Filling system variables (X3) and e-Billing system variables (X4) show that all items of the questionnaire statement were declared valid because the correlation coefficient for each item is greater than or equal to 0,279 $\left(r_{\text {count }} \geq r_{\text {table }}\right)$ and the significance level is 0,05 . Thus, it can be stated that all statements are declared valid researchers that can be used as a sample, if viewed by people who happen to be found suitable as a source of data. The sample of this study was Tax Accounting Students at Bina Bangsa University class of 2015 who filled in a questionnaire of 55 students.

\subsection{Data Collection Techniques}

Data collection used in this study was a questionnaire method (Questionnaire). Questionnaire is a data collection technique that is done by giving a set of written questions to respondents to be answered, can be given in person or by post or internet. There are two types of questionnaires, namely closed and open. The questionnaire used in this study is a closed questionnaire that is a questionnaire that has been provided the answer, so that the respondents just choose and answer directly.

and can be trusted in taking research data.

From the result of the reliability test it can be concluded that all questionnaires of the the five variables are reliable, because Alpha Cronbach's value is more than 0,60 . So that the questionnaire can be used more than once with the same respondent.

To find out the data used in research normally distributed or not then normality test is used. The normality test in this study is the Kolmogorov-smirnov test. The basis for decision making is based on the resulting Sigfinikansi value, with the following conditions: 1) If the 
Significance value is less than 0.05 then $\mathrm{Ho}$ is rejected and $\mathrm{Ha}$ is accepted. In other words, data is not normally distributed. 2) If the Significance value is more than 0.05 then $\mathrm{Ho}$ is accepted and $\mathrm{Ha}$ is rejected. In other words, data is normally distributed. Following the Kolmogorov-Smirnov test results:

Table 1: One Sample Kolmogorov-Smirnov Test

\begin{tabular}{|c|c|c|c|c|c|}
\hline & & $\begin{array}{c}\text { Unstandardized } \\
\text { Residual }\end{array}$ & $\begin{array}{c}\text { Unstandardized } \\
\text { Residual }\end{array}$ & $\begin{array}{c}\text { Unstandardized } \\
\text { Residual }\end{array}$ & $\begin{array}{c}\text { Unstandardized } \\
\text { Residual }\end{array}$ \\
\hline \multicolumn{2}{|l|}{$\mathrm{N}$} & 55 & 55 & 55 & 55 \\
\hline \multirow{3}{*}{ Normal Parameters sh } & Mean & .0000000 & .0000000 & .0000000 & .0000000 \\
\hline & Std. Deviation & 2.33721255 & 2.70696936 & 2.64595294 & 2.79620156 \\
\hline & Absolute & .108 & .117 & .070 & .095 \\
\hline \multirow[t]{2}{*}{ MostExtreme Differences } & Positive & .102 & .117 & .063 & .095 \\
\hline & Negative & -108 & -087 & -.070 & -.081 \\
\hline Kolmegoreve-SmirnovZ & & .797 & .867 & .517 & .703 \\
\hline Asymp. Sig. (2-tailed) & & .549 & .439 & .952 & .707 \\
\hline
\end{tabular}

From Table 4.1 it can be seen in the Kolmogorov-smirnov column and it can be seen that the significance value for all variables is $0.549 ; 0.439 ; 0.952$ and 0.707 is greater than 0.05 . Then it can be concluded that the population data of all variables in this study are normally distributed.

The results of multicollinearity testing using Variance Inflator Factor (VIF). VIF limit is not more than 10, if the analysis shows that VIF is below 10 then multicollinearity does not occur. Conversely, if the VIF results are above 10, then multicollinearity occurs. Here are the results of multicollinearity:

Table 4.2 Multicolinearity Test

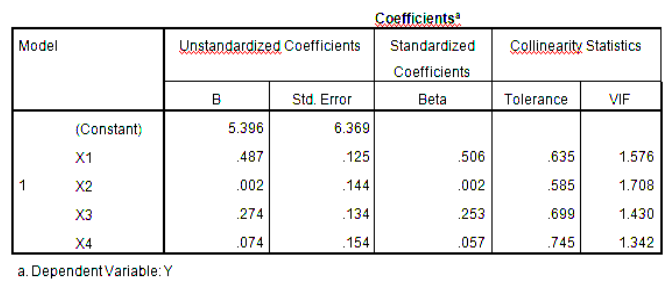

From Table 4.2 it can be seen in the VIF for e-registration variable (X1) is 1.576, e-spt variable (X2) is 1.708 , e-filing variable (X3) is 1.430 , and e-billing variable (X4) is 1.342 . This means that the variables in this study do not have multicollinearity problems because the VIF values of all the independent variables are below 10 .

To find out whether or not there is a classic assumption deviation, the heteroscedasticity test is used, which means the variance inequality of the residuals of all regression models. The prerequisites that must be met in the heteroscedasticity model can be seen from the plot graph of the analysis results.

From the results of testing the assumption of heteroscedasticity through the scatter plot it can be seen that the points spread between the zero point of the $y$ axis without forming a pattern. Then the regression model has the same variance or heteroscedasticity does not occur.

\section{Hipothesis Testing}

Table 3: Coefficient Table

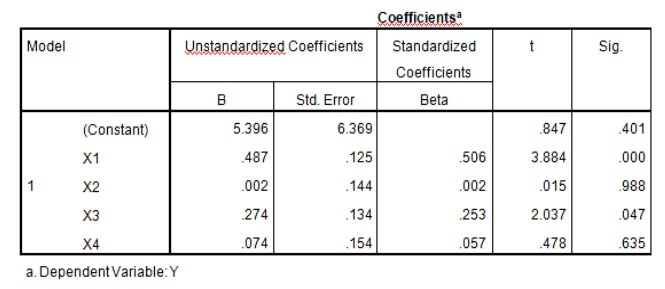

From Table 4.3, the regression result can be made as follows:

$\mathrm{Y}=\mathrm{a}+\mathrm{b} 1 \mathrm{X} 1+\mathrm{b} 2 \mathrm{X} 2+\mathrm{b} 3 \mathrm{X} 3+$ b4X4+e

$\mathrm{Y}=5,396+0,487 \mathrm{X} 1+0.002 \mathrm{X} 2+$

$$
0.274 \mathrm{X} 3+0,074 \mathrm{X} 4+\mathrm{e}
$$




\section{T Test Results}

First Hypothesis testing results. The first hypothesis of this study states that, e-registration (X1) affects the understanding of accounting students. From the outputs Table 4.3 it can be seen that the e-registration variable (X1) has sig. of 0,000 .

The second hypothesis be concluded that the application of espt system (X2) does not affect the understanding of accounting students. From the outputs Table 4.3 it can be seen that the e-spt (X2) variable has sig. amounted to 0.988 .

Third Hypothesis testing results that the application of e-filing system (X3) affects the understanding of accounting students. From the outputs Table 4.3 it can be seen that the e-filing system variable (X3) has sig. in the amount of 0.004 .

The fourth Hypothesis test results that the application of e-billing system (X4) does not affect the

\subsection{Discussion}

This study used a sample of 55 accounting students at Bina Bangsa University. The independent variable in this study is the application of e-registration system, e-spt system, e-filing system, and ebilling system. While the dependent variable is the understanding of accounting students. This study aims to determine the effect of applying eregistration, e-spt, e-filing, e-billing to the understanding of accounting student.

The researcher uses the statistic test starting with descriptive statistical testing then the classical assumption test and finally the hypothesis testing to find out how the feasibility of the regression understanding of accounting students. From the outputs in table 4.3 it can be seen that the e-billing system variable (X4) has sig. amounted to 0.635 .

\section{F Test Results}

F Test Results, can be seen from the following table 4.4:

Table 4: ANOVA Result

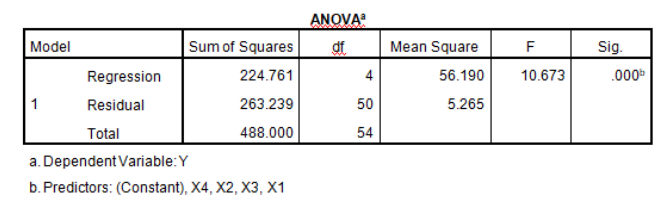

Fifth Hypothesis testing results that the simultaneous application of e-registration system (X1), e-spt system (X2), e-filling system (X3) and e-billing system(X4) influences the understanding of accounting students (Y). From the outputs table 4.4 it can be seen that having sig. by 0,000 smaller than 0.05 .

model used for research. Data processing and hypothesis testing in this study were carried out using SPSS v.21 for windows software. Based on testing the hypothesis that has been done, it can be concluded as follows:

1. The application of eregistration has a significan effect on the understanding of accounting students because the e-registration system variable (X1) has sig. 0.000 which is smaller than 0.05 . This significance value is smaller than 0.05 then $\mathrm{H} 1$ is accepted which means the application of e-registration system has a significant effect on the understanding of 
accounting students. The results same as the results of previous studies conducted by Widjaja \& Siagian (2017), which states the use of eregistration has a positive and significant effect on tax obligations.

2. The application of e-spt has an insignificant effect on the tax liability of personal taxpayers because the e-spt (X2) variable has sig. Of 0.988, which is greater than 0.05. This significance value is greater than 0.05 then $\mathrm{H} 2$ is rejected which means the application of e-spt does not significantly influence the understanding of accounting students. From the results of the study is not in line with Rahmatunnisa (2016) which states that the E-SPT variable influences student understanding.

3. The application of e-filing has a significant effect on the tax liability of personal taxpayers because the e-filling variable (X3) has sig. 0.00 less than 0.05 . This significance value is smaller than 0.05 then $\mathrm{H} 3$ is accepted which means the application of e-filing has a significant effect on the understanding of accounting students. From the results of the study is in line with Rahmatunnisa (2016) which states that the e-filling variable influences student understanding.

4. The application of e-billing has an insignificant effect on the tax liability of personal taxpayers because the e-billing variable has sig. 0.635 is greater than 0.05. This significance value is greater than 0.05 , so $\mathrm{H} 4$ is rejected, which means the application of e-billing does not significantly influence the understanding of accounting students. From the results of the study is not in line with Rahmatunnisa (2016) which states that e-billing variables affect student understanding.

5. The fifth hypothesis that the simultaneous application of eregistration (X1), e-spt (X2), efilling (X3) and e-billing (X4) influences the understanding of accounting students (Y). From the outputs in table 4.4 it can be seen that having sig. by 0,000 smaller than 0.05 . This significance value is less than 0.05 then $\mathrm{H} 5$ is accepted which means the application of eregistration (X1), e-spt (X2), efilling (X3) and e-billing (X4) significantly influences the understanding of accounting students. From the results of the study is in line with Rahmatunnisa (2016) which states that the variable tax technology affects student understanding.

\section{CONCLUSION}

\subsection{Conclusion}

This study is to examine how effect the application of taxation online e-system to the understanding of accounting students at Bina Bangsa University is proxied by eregistration system, e-spt system, e- 
filling system and e-billing system. From the results of previous tests, researchers can be concluded as follows:

1. From the first result $(\mathrm{H} 1)$ that $\mathrm{H} 1$ is accepted which means the application of e-registration has a significant effect on the understanding of accounting students.

2. From the second result $(\mathrm{H} 2)$ that $\mathrm{H} 2$ is rejected which means the application of e-spt does not significantly influence the understanding of accounting students.

3. From the third result $(\mathrm{H} 3)$ that H3 is accepted which means the application of e-filing has a significant effect on the understanding of accounting students.

4. From the fourth results (H4) that $\mathrm{H} 4$ is rejected which means the application of ebilling does not significantly influence the understanding of accounting students.

5. From the fifth results (H5) that H5 is accepted which means it can be concluded that the simultaneous application of eregistration system, e-spt system, e-filling system and ebilling system significantly influences the understanding of accounting students.

\section{REFERENCES}

Ayu Gustiani, (2014). Penaruh Penerapan e-SPT dan Pengetahuan Perpajakan terhadap Kepatuhan Wajib

\subsection{Implication}

Based on the results of this hypothesis which states that the application of e-taxation systems that have different variants and applications prove that there is no reason for students not to learn and understand tax technology, this is due to demands for an understanding of tax technology that must be studied and applied lectures to support students' skills or abilities in taxation information, both technological and theoretical.

\subsection{Suggestion}

In the future, this research is expected be able to present highquality research results with the presence of some input on several matters including:

1. For further research is expected to expand the research sample not only to students in the scope of a single university.

2. For the University to add an understanding of e-taxation systems as curriculum in the learning plan.

3. For students, especially those who concentrate on tax accounting, so that they are always updated about the etaxation system.
Pajak di Kantor Pelayanan Pajak Pratama Karees Bandung, UNIKOM Repository: Bandung.

Elmasita Fauzizah Sukmayanti, (2018). Pengaruh Penerapane- 
EAJ (Economics and Accounting Journal) - Vol. 3, No. 1, Jan 2020 - Khodijah, Afriani

Billing, pemahaman peraturan pemerintah nomor 46 tahun 2013, dan sanksi perpajakan terhadap kepatuhan wajib pajak UMKM pada KPP Pratama Magelang. Yogyakarta: UNY

K Karmila, (2019). Pengaruh TAM Terhadap Kepatuhan Wajib Pajak dengan Penggunaan EFiling Sebagai Variabel Intervening pada KPP Pratama Sukoharjo (http://eprints.ums.ac.id/42031 /6/BAB\%20I.pdf)

Mardiasmo, (2018). Perpajakan, Yogyakarta: Andi Yogyakarta,

Nita Rysaka, Choirul Saleh, Stefanus Pani Rengu, (2014) Penerapan Sistem Elektronik Dalam Pelayanan Perpajakan. Administrasi publik student journal. 2(3),

Putra Purnama, (2015). Analisis tingkat pemahaman mahasiswa terhadap pernyataan standar akuntansi keuangan syariah
PSAK - Syariah, JRAK, 6(1), 38-50.

Rahmatunnisa, Siti Khairani, dan Raisa Pratiwi, (2016). Pemahaman mahasiswa akuntansi terhadap teknologi pajak, Palembang: STIE MDP Repository.

Riyanto, Heri Tavip, (2014). Pemahaman mahasiswa program studi akuntansi fakultas ekonomi dan bisnis, Palembang: UMP Repository.

Saputra, Egi Nugraha. (2013). Pengaruh kualitas teknologi informasi dan penerapan $e$ filling terhadap kualitas pelayanan, Bandung: UNIKOM Repository.

Sugiyono, (2012). Metode Penelitian Bisnis, Bandung: Alfabeta

Waluyo (2017). Perpajakan Indonesia. Jakarta: Salemba Empat. 